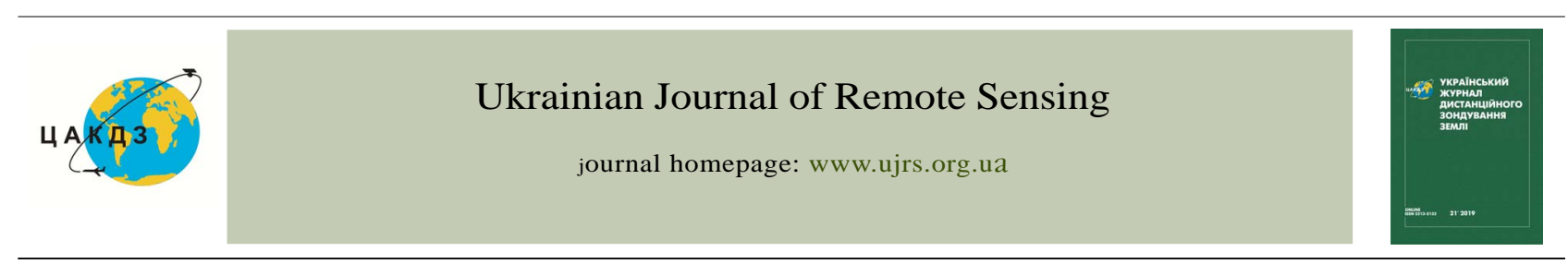

DOI: https://doi.org/10.36023/ujrs.2019.22.153

UDC (528.831.1/.4:633.003.13):629.783](4)

\title{
Spatio-temporal trend analysis of vegetation productivity in Europe using MODIS data sets
}

\author{
D. M. Movchan * \\ Scientific Centre for Aerospace Research of the Earth, National Academy of Sciences of Ukraine, 01054 Kyiv, Ukraine
}

Some previous studies showed that ecosystem biogeochemical processes were significantly affected by variation of the temperature regime. For example, experimental warming led to photosynthesis intensification and increasing of the vegetation productivity and biomass accumulation (Elmendorf et al., 2012; Lin et al., 2010; Lu et al., 2013; Wu et al., 2011). However, such association is not so clear under natural conditions (Mohamed et al., 2004). This study provides the results of a pixel-wise trend analysis which has been performed to identify regional trends in the vegetation productivity for the European territory over the last 14 years. The moderate-resolution imaging spectroradiometer (MODIS) time series data have been used to analyse net primary productivity (NPP) trends. The changes in terrestrial carbon stock caused by the dynamics of vegetation productivity have been estimated. The negative trend of the vegetation productivity was found for Eastern Europe. It was found that the increased summer temperatures negatively influenced the vegetation productivity in Western, Eastern and Southern Europe. The findings suggest that the mean summer temperatures have reached a threshold in Southern Europe and its subsequent growth would lead to reducing the vegetation productivity. At the same time in the northern regions, the threshold has not been reached; therefore, summer temperatures increasing will stimulate the growth of vegetation. Analysing the changes for different types of vegetation it can be noted that the carbon stocks of agricultural land have been decreased by $2.67 \mathrm{Mt} C$, while forests and savannah areas have positive dynamic (the carbon stocks have been increased by 1.64 and 3.7 Mt C respectively). Summary results for the whole European region indicate a positive trend $(2.67 \mathrm{Mt})$ of $\mathrm{C}$ stock in the terrestrial vegetation.

Keywords: vegetation productivity; climate change; remote sensing; carbon stock; MODIS

(C) D. M. Movchan. 2019

\section{Introduction}

Greenhouse gases (GHG) concentration in the atmosphere is an important component of the global climate system. It absorbs thermal infrared radiation emitted by the surface of our planet and, thereby, affects the temperature regime of the planet (IPCC, 2001). The atmosphere is a very dynamic system. According to the reports of the Intergovernmental Panel on Climate Change (IPCC), increasing of GHG concentration in the atmosphere that occurred during the last decades, entailed intensification of radioactive forcing of the long-lived GHG by 9\% for period $1998-2005$ (IPCC, 2007) and by $7.5 \%$ for $2005-$ 2011 (IPCC, 2013). And about $80 \%$ of this effect is generated by carbon dioxide $\left(\mathrm{CO}_{2}\right)$.

Terrestrial ecosystems are a major player in interaction between the land surface and the atmosphere. They can release or absorb globally relevant greenhouse gases, and they control exchanges of energy and water between these geospheres (Heimann \& Reichstein, 2008). Ecosystems themselves are subject to climatic conditions. They store large amount of carbon in living vegetation, and release of this carbon into the atmosphere could have tremendous consequences. There are two main factors which generate changes in carbon fluxes between the atmosphere and terrestrial ecosystems: i) land use changes (deforestation, irrigation, melioration etc.) and ii)

\footnotetext{
* E-mail: dmovchan@hotmail.com (D. M. Movchan). ORCID: 0000-0003-0176-7740
}

changes in the vegetation productivity and biomass stocks as a physiological reaction of plants on climate changes (Houghton, 2005; Zhou et al., 2001; de Jong et al., 2013; Mohamed et al., 2004; Piao et al., 2005; Groisman \& Lyalko, 2012).

It is assumed that terrestrial ecosystems will provide a positive feedback in a warming world on a global scale. The changes of climate factors have various strengths and directions depending on geographic location, and different ecosystems have various sensitivities to climate changes (Mohamed et al., 2004). The regional feedbacks, nevertheless, are hardly predicted because of different ecosystem reactions within diverse geographical regions. For example, annual tree growth in tropical forests has shown a negative correlation with temperature (Clark et al., 2008). And this negative response of vegetation productivity to mean annual temperature (MAT) variability may arise from the fact that tropical forests already operate near to a high-temperature optimum above which photosynthesis rate declines (Piao et al., 2013; Corlett, 2011). In boreal regions, vegetation growth is limited by temperature through the control of the growing season length (Piao et al., 2013; 2007; However, de Jong et al., 2013) reported that deciduous needleleaf forests show reduced vegetation activity despite the warming trend. In temperate regions, the response of GPP to MAT depends on the balance between the positive effect of warming through extending the growing season in spring and the negative effect of warming through enhanced soil moisture stress in summer (Piao et al., 2013). Some recent work also suggests that the length of photoperiod may limit GPP (Bauerle et al., 2012). 


\section{Methods and data}

\section{Vegetation productivity data}

Among all methods, only satellite observations provide the global spatially continual observations of the vegetation productivity. The production efficiency models (PEMs) have been developed to monitor the primary production, taking advantage of the available satellite data (Mc Callum et al., 2009). The PEMs are based on the theory of the light use efficiency (LUE) which states that a relatively constant relationship exists between the photosynthetic carbon uptake and radiation absorption by vegetation at the canopy level (Anderson et al., 2000). The U.S. National Aeronautics and Space Administration (NASA) Earth Observing System (EOS) currently produces a regular global estimate of GPP and NPP of the entire terrestrial Earth's surface at 1-km spatial resolution (MOD17 model) (Running et al., 2000). The core science of the algorithm is an application of the radiation conversion efficiency concept to predictions of daily GPP, using satellite-derived FAPAR (from MOD15) and independent estimates of PAR and other surface meteorological fields (Heinsch et al., 2003):

$$
G P P=\varepsilon \times F P A R \times P A R \times S_{T \min } \times S_{V P D}
$$

where, GPP — gross primary productivity ( $\mathrm{g} \mathrm{C} \mathrm{m-2);} \mathrm{PAR} \mathrm{-}$ photosynthetically active radiation $(\mathrm{MJ} \mathrm{m}-2)$; FAPAR — fraction of absorbed PAR (dimensionless \%); $\varepsilon$ - light use efficiency (g C MJ-1); STmin - daily minimum temperature scalar, SVPD vapor pressure deficit scalar $(0-1)$.

The subsequent estimation of maintenance (MR) and growth (GR) respiration terms that are subtracted from GPP to obtain annual NPP (Heinsch et al., 2003):

$$
N P P=G P P-M R-G R
$$

The data from the Collection 5 of the MOD17A3 model were used. The data are freely available via the Atmosphere Archive and Distribution System (LAADS) of the NASA (http:// ladsweb.nascom.nasa.gov/). The MOD17A3 is an annual sum of the GPP and NPP. The model is based on data obtained from the MODIS spectrometer located on the Terra and Aqua platforms. The spatial resolution of the model is $1 \times 1 \mathrm{~km}$, which allows assessing of the GPP and NPP at the regional and local levels. The data set contains the observations for 14 years (from 2000 through 2013). The uncertainty of the model was estimated about $13-15 \%$. There are two main sources of the uncertainty. Firstly, the MOD12Q1 land cover product used in the model has accuracy in the range of $70-80 \%$, and most of the mistakes are between similar classes (Strahler et al., 2002). Secondly, large-scale meteorological data are provided by the NASA Data Assimilation Office (DAO). These data are derived using a global circulation model (GCM). Preliminary studies done by the Numerical Terradynamic Simulation Group (NTSG) suggest that the relationship between surface observations and DAO data across the U.S. appears reasonable, but comparisons have yet to be made on a global scale (Heinsch et al., 2003). As a result, it may contain systematic errors in some regions. The uncertainties in meteorological data are mainly responsible for the unrealistic GPP in some small regions. For these pixels located in harsh environments, overestimated temperature alone, for example, can be enough to produce underestimation of the GPP due to the higher Vapor Pressure Deficit (VPD). A detailed discussion about the MOD17 algorithm sensitivity to meteorological inputs can be found elsewhere (Zhao et al., 2006).

\section{Temperature data}

Data about 2-meter air temperature was obtained from the ERA-Interim global atmospheric reanalysis (Dee et al., 2011) produced by the European Centre for Medium-Range Weather Forecasts (ECMWF) (http://www.ecmwf.int/en/research/ climate-reanalysis/era-interim). The ERA-Interim data sets contain a data at different levels: analysis fields, forecast fields and fields available from both the analysis and forecast. The data from step 0 that correspond to only analysis fields and which were produced for 12:00 UTC have been used. The data set is based on the regular grid with $0.125 \times 0.125$ degree spatial resolution. The temperature parameters (Table1) have been calculated using daily data for each year between 2000 and 2013. After that, the data were interpolated to $1 \times 1 \mathrm{~km}$ spatial resolution using an original kriging approach for spatial harmonization with the MOD17A3 Product data.

Table 1.

Parameters of the temperature regime calculated from the ECMWF data set 30 . Each parameter is represented in a grid with 0.125 degree spatial resolution

\begin{tabular}{lll}
\hline Parameter & Label & Unit \\
\hline Me an annual te mpe rature & MAT & ${ }^{\circ} \mathrm{C}$ \\
Me an winter te mp erature & $\mathrm{MT}_{\text {win }}$ & ${ }^{\circ} \mathrm{C}$ \\
Me an spring temperature & $\mathrm{MT}_{\text {spr }}$ & ${ }^{\circ} \mathrm{C}$ \\
Me an summer temperature & $\mathrm{MT}_{\text {sum }}$ & ${ }^{\circ} \mathrm{C}$ \\
Me an autumn temperature & $\mathrm{MT}_{\text {aut }}$ & ${ }^{\circ} \mathrm{C}$ \\
Numbers of days with temperature above $0{ }^{\circ} \mathrm{C}$ & $\mathrm{ND}^{\circ}$ & days \\
Numbers of days with temperature above $5{ }^{\circ} \mathrm{C}$ & $\mathrm{ND} 5$ & days \\
Numbers of days with temperature above $25^{\circ} \mathrm{C}$ & $\mathrm{ND} 25$ & days \\
\hline
\end{tabular}

\section{Land cover data}

The MOD12Q1 Land Cover Type Product supplies global maps of land cover at $1 \mathrm{~km}$ spatial resolution. The IGBP land cover scheme provided by the International GeosphereBiosphere Programme (IGBP) (http://www.igbp.net) was used. The MOD12Q1 is a global product and has detailed classification scheme (17 classes). Whereas such detail classification is not necessary for the study, the reclassification with aggregation of main vegetation classes (forest, grass- \& shrublands (savannas) and croplands) has been done (Table 2). This reclassification also should lead to rising of the classification accuracy since most mistakes are between similar classes.

\section{Analysis}

A general concept of the data collection, processing and analyzing is shown in Fig. 1. Temperature parameters have been calculated from the downloaded temperature data. After that, the data sets were spatially and temporally harmonized with the vegetation productivity data. The pixel-wise trend analysis has been performed to identify trends of certain parameters $\left(\mathrm{P}_{\mathrm{i}}\right)$ for each pixel $(x)$ using linear regression:

$$
P_{i, x}=\beta_{0}+\beta_{1} \times \text { time }_{x}+\varepsilon_{x}
$$

The slope $\left(\beta_{1}\right)$ has been multiplied by the number of years to obtain the value of change in the parameters. 
Table 2.

Reclassification of the MOD12Q1 Land Cover Type Product with aggregation of main vegetation classes

\begin{tabular}{|c|c|c|c|}
\hline IGBP Class & Label & New Class & Label \\
\hline 1 & Evergreen Needl eleaf forest & 1 & Forest \\
\hline 3 & Deciduous Needleleaf forest & 1 & Forest \\
\hline 4 & Deciduous Broadleaf forest & 1 & Forest \\
\hline 5 & Mixed forest & 1 & Forest \\
\hline 8 & Woody sa vann as & 2 & Savannas \\
\hline 9 & Savannas & 2 & Savannas \\
\hline 10 & Gras slan ds & 2 & Savannas \\
\hline 11 & Permanent wetl ands & 2 & Savannas \\
\hline 12 & Cropland s & 3 & Croplands \\
\hline 13 & Urban and built-up & 0 & Non vegetation \\
\hline 255 & Fill Value & 0 & Non vegetation \\
\hline
\end{tabular}

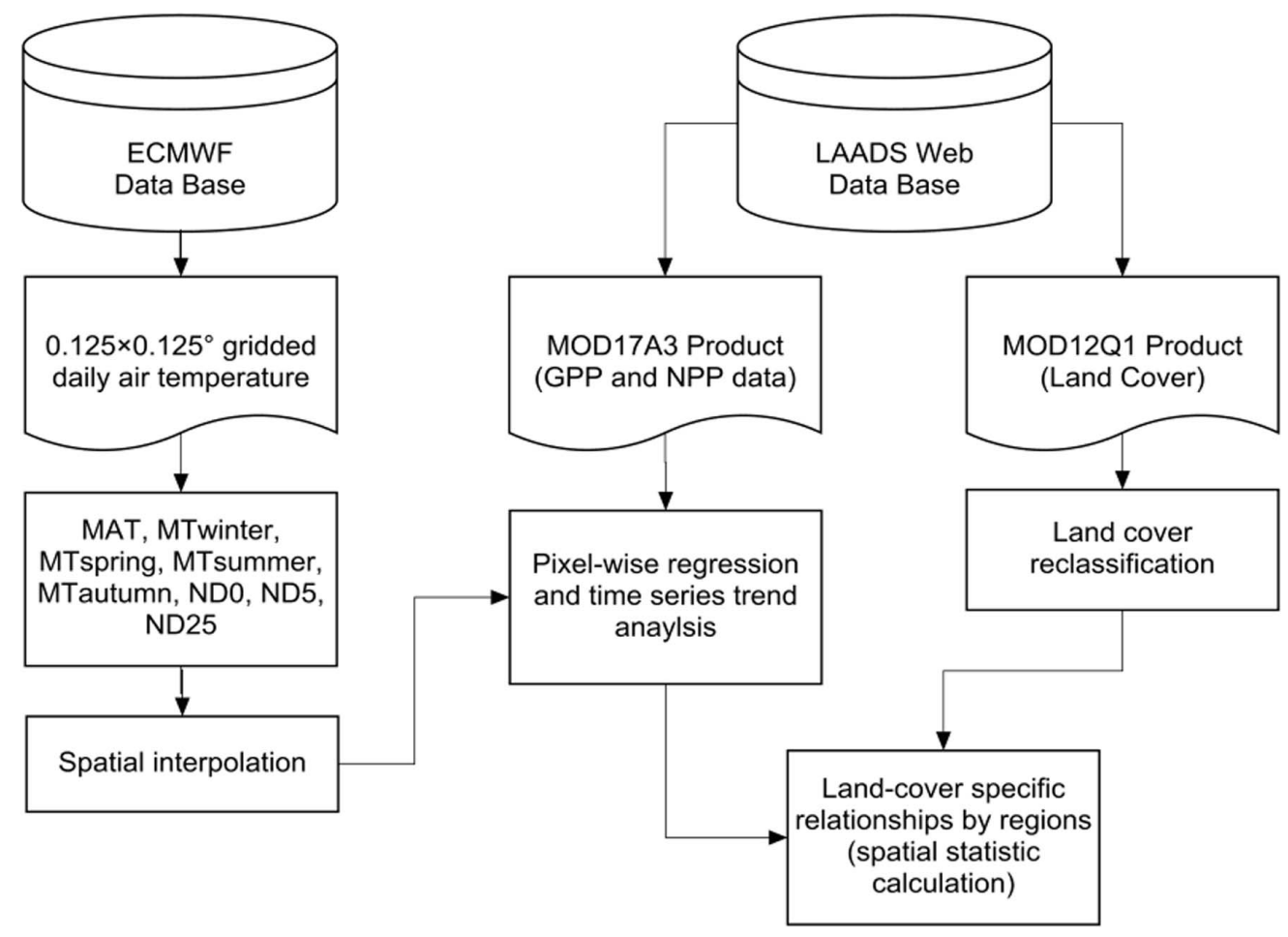

Fig. 1. General concept of the data collection, processing and analyzing

The pixel-wise regression has also been used to find correlation between vegetation productivity and temperature parameters $\left(\mathrm{P}_{\mathrm{i}}\right)$ for each pixel $(x)$ :

$$
N P P_{x}=\beta_{0}+\beta_{1} \times P_{i, x}+\varepsilon_{x}
$$

Finally, the statistic has been calculated to estimate significance (p-value) of the results.

The data analysis was performed for each land cover class within each European region to identify differences in relations between the vegetation productivity and temperature parameters between these regions. The geographical region and sub-region grouping scheme from the United Nations Statistics Division (http://unstats.un.org/unsd/default.htm) has been used (the territory of European Russia is not accounted in the calculation). All the algorithms and statistical treatments were implemented with $\mathrm{R}$ software (http://www.r-project.org/).

The data that support the findings of this study are available from the corresponding author upon reasonable request. 


\section{Results}

\section{Regional trends of the vegetation productivity}

The territory of Europe has a broad latitudinal extent that defines climatic heterogeneity of the regions from north to south and causes ecosystem diversity. The various types of ecosystems respond differently to climate changes (Heimann \& Reichstein, 2008; Movchan \& Kostyuchenko, 2015). For example, Frank, D. et al. (2015) deduced that climate extreme of a certain magnitude will not have the same impact on forest, grasslands or croplands. Therefore, the vegetation productivity trends of various land-use classes for the European regions have been calculated to identify such differences.

The results of a pixel-wise trend analysis averaged by regions and land cover types over Europe show that the vegetation productivity (NPP) did not change significantly for most of the European territory. Only 8.3\% (465 $247.3 \mathrm{sq} \mathrm{km}$ ) of the total vegetation area showed a significant change in NPP (Fig. 2). Herewith 3.6\% (200 $039.6 \mathrm{sq} \mathrm{km})$ of this change had decreasing trend and 4.7\% (265 $207.7 \mathrm{sq} \mathrm{km})$ were positive.

The regional distribution of the vegetation productivity trends shows that area of the statistically significant NPP trends in Southern and Eastern Europe has been larger (12\% and 9\% of the total vegetation area respectively) than in Western and Northern Europe (about $5 \%$ of the total vegetation area in both cases). Meanwhile, in Southern Europe, such trend has a clear positive dynamic, while poor predomination of negative one take place in Northern Europe. The distribution of the trend directions for Western and Eastern Europe is approximately equal.

The distribution of the vegetation productivity trends within different land-use classes is presented in Table 3 . We can see that croplands have the largest areas with the statistically significant vegetation productivity trends (14\% of the total cropland area) with a slight predominance of positive tendency. For the forest, such areas cover $5 \%$ of total area and the trend has a clear positive tendency. Savannas' vegetation showed the slightest NPP change (about $4-5 \%$ of the total area) with absolute predomination of positive tendency.

Using this areal valuation and taking into consideration amplitudes of the trends (Table 4) calculated for each region, the changes in terrestrial vegetation carbon stock during last 14 years have been investigated. The results showed that the most significant changes in carbon stocks took place in Eastern and Southern Europe. In Eastern Europe carbon stocks of terrestrial vegetation were reduced by $5.26 \mathrm{Mt} \mathrm{C}$. This reduction was mainly due to agricultural land $(-4.6 \mathrm{Mt} \mathrm{C})$. In Southern Europe
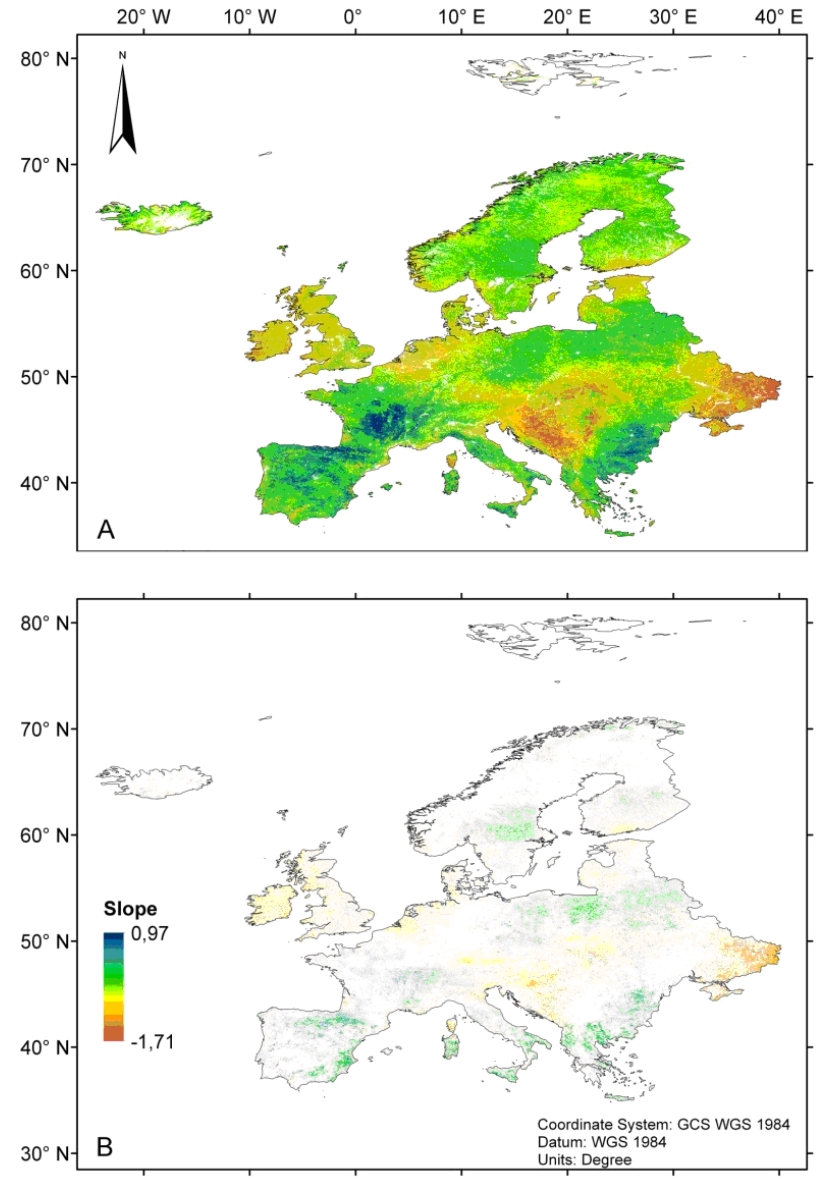

Fig. 2. Spatial distribution of the NPP trends ( $\mathrm{kg} \mathrm{C} \mathrm{m-2)} \mathrm{over} \mathrm{Europe:}$ for the whole territory (a) and for pixels with statistical significance (b) (p-value $<0.05)$

the carbon stocks were increased by $8.06 \mathrm{Mt} \mathrm{C}$. A significant increase was observed for both agricultural land $(4.2 \mathrm{Mt} \mathrm{C})$ and for savanna (3.16 Mt C). C stocks changes in other regions were unessential.

Analysing the changes for different types of vegetation it can be noted decreasing in $\mathrm{C}$ stocks for agricultural land (-2.67 Mt C) and increasing stocks for forests and savannah (1.64 and 3.7 Mt C respectively). Summary results for the whole European region indicate a positive trend $(2.67 \mathrm{Mt})$ of $\mathrm{C}$ stock in the terrestrial vegetation.

Table 3.

Distribution of areas (sq km) with statistically significant trend of vegetation productivity (NPP) within different land-use classes for each European region

\begin{tabular}{|c|c|c|c|c|c|c|c|c|}
\hline Land -use & Croplands & & Forest & & Savannas & & Total & \\
\hline Trend & Negative & Positive & Negative & Positive & Negative & Positive & Negative & Positive \\
\hline Western Europe & 19666.8 & 12616.4 & 6744.4 & 8947.4 & 314.4 & 4033.3 & 26725.7 & 25597.1 \\
\hline Eastem Europe & 93701.2 & 85953.2 & 10679.9 & 8849.6 & 456.0 & 318.6 & 104837.1 & 95121.3 \\
\hline Northern Europe & 24978.7 & 4597.6 & 12526.8 & 29182.7 & 1819.9 & 8060.4 & 39325.4 & 41840.7 \\
\hline Southem Europe & 20984.9 & 61220.2 & 5572.1 & 9155.6 & 2594.5 & 32272.8 & 29151.5 & 102648.6 \\
\hline Total & 159331.6 & 164387.3 & 35523.2 & 56135.4 & 5184.8 & 44685.1 & 200039.6 & 265207.7 \\
\hline
\end{tabular}


Table 4.

Averaged amplitudes of NPP trends ( $\mathrm{kg} \mathrm{C} \mathrm{m-2)}$ for the areas with negative and positive dynamics for each region

\begin{tabular}{lllllll}
\hline & $\begin{array}{c}\text { Land-use } \\
\text { class }\end{array}$ & Croplands & & Forest & & \multicolumn{2}{l}{ Savannas } \\
Region & & & & & & \\
\hline Trend & Negative & Positive & Negative & Positive & Negative & Positive \\
Western Europe & -0.0851 & 0.0985 & -0.0953 & 0.1623 & -0.1026 & 0.0728 \\
Eastem Europe & -0.1264 & 0.0843 & -0.1295 & 0.0845 & -0.1146 & 0.0881 \\
Northern Europe & -0.0889 & 0.0827 & -0.0830 & 0.0620 & -0.0692 & 0.0532 \\
Southem Europe & -0.0972 & 0.1019 & -0.1357 & 0.1586 & -0.1404 & 0.1093 \\
\hline
\end{tabular}

\section{Relations of the vegetation productivity and temperature regime}

MAT is one of the key parameters used for climate studies to describe the temperature regime of a territory (IPCC, 2001; Hartmann et al. 2013; Bonnaventure \& Lewkowicz 2013). However, it is not an appropriate parameter to assess the impact of temperature regime on the vegetation productivity since plants react mainly to extremes rather than the average temperatures. In this case, the seasonal distribution of air temperature and duration of periods with extreme temperature conditions is more important. Therefore, mean winter (MTwin), spring (MTspr), summer (MTsum) and autumn (MTaut) temperatures have been used in the study. The number of days with temperatures above $0^{\circ} \mathrm{C}$ (ND0) and above $5^{\circ} \mathrm{C}$ (ND5) has also been calculated to assess the response of vegetation on variations in the growing season length. And the number of days with temperatures above $25^{\circ} \mathrm{C}$ (ND25) has been used to assess the response of vegetation on the periods with extremely high temperatures and its duration.

The results of the regression analysis did not show a clear relationship between changes in the vegetation productivity and parameters such as MAT, MTwin, MTspr, MTaut, ND0, and ND5. Per-pixel analysis showed that the most of the study area does not have a statistical significance of the relationship. This means that changes of above-listed parameters do not affect the dynamic of the vegetation productivity and were not limiting or stimulating factor for the vegetation growing (except small areas).

The relation between the dynamics of the vegetation productivity and ND25 was statistically significant only for Western and Southern Europe (Table 5, Fig. 3). Therewith, the relation was negative in all cases and increasing of the period's duration led to the productivity reduction. It means that increasing of ND25 was the limiting factor for the vegetative growth in certain areas.

The similar analysis for MTsum (Table 5, Fig. 4) shows that the vegetation productivity was more sensitive to summer temperature increasing. The response was statistically significant almost for all cases (except forests and savannas in Eastern and croplands in North Europe). And unlike ND25 case, this relation was not uniform. The northern regions have a positive relation, while negative dependence prevailed within other parts of Europe.

\section{Discussion and Conclusions}

The results showed that the mean summer temperature has the strongest impact on the vegetation productivity dynamic among all the temperature parameters. The increasing of summer temperatures caused the strongest statistically significant response of the vegetation over a substantial part of the study area. And the statements about the spatial heterogeneity of such response across a latitudinal gradient and varying sensitivity of different types of the vegetation to climate change (Houghton, 2005, Zhou et al., 2001, de Jong et al., 2013, Mu et al., 2011, Mohamed et al., 2004, Piao et al., 2005, Elmendorf et al., 2011, Frank et al., 2015, Zhang et al., 2007) have been confirmed by the results.

The increased summer temperatures negatively influenced the croplands productivity in Western, Eastern and Southern Europe., The effect has been absent in Northern Europe. In addition, the intensity of the impact grows towards lowering latitudes. Gornall et al. (2010), Porter and Semenov (2005) have shown that even in the middle latitudes croplands decrease its productivity under high temperatures without proper adaptation. And it agrees with the obtained results. The absence of the dependence for the higher latitudes can be explained by the fact that the summer temperatures increasing did not reach critical values and did not cross the threshold in northern regions.

Forest ecosystems have a lower threshold to extremely high temperatures (Bun' et al., 2004). And the results are consistent with this. The finding shows that forest is significantly more responsive to growing summer temperatures compared to croplands. Moreover, this reaction varies in the latitudinal direction. The negative effect is predominated in low and

Table 5.

The regression coefficients of the pixel-wise regression for MTsum and ND25 averaged by the regions and land-use classes( sns - statistically nonsignificant)

\begin{tabular}{|c|c|c|c|c|}
\hline Land-use class & Western Europe & Eastern Europe & $\begin{array}{l}\text { Northern } \\
\text { Europe }\end{array}$ & $\begin{array}{l}\text { Southern } \\
\text { Europe }\end{array}$ \\
\hline $\begin{array}{l}\mathrm{MT}_{\text {sum }} \\
\text { Croplands } \\
\text { Fo rest } \\
\text { Savannas } \\
\end{array}$ & $\begin{array}{l}-0.0291 \\
-0.0385 \\
-0.0434 \\
\end{array}$ & $\begin{array}{l}-0.0261 \\
\text { sns } \\
\text { sns }\end{array}$ & $\begin{array}{l}\text { sns } \\
0.0188 \\
0.016\end{array}$ & $\begin{array}{l}-0.0295 \\
-0.0445 \\
-0.037\end{array}$ \\
\hline $\begin{array}{l}\text { ND25 } \\
\text { Croplands } \\
\text { Fo rest } \\
\text { Savannas }\end{array}$ & $\begin{array}{l}-0.0035 \\
-0.005 \\
-0.005\end{array}$ & $\begin{array}{l}\text { sns } \\
\text { sns } \\
\text { sns }\end{array}$ & $\begin{array}{l}\text { sns } \\
\text { sns } \\
\text { sns }\end{array}$ & $\begin{array}{l}-0.0026 \\
-0.0042 \\
\text { sns }\end{array}$ \\
\hline
\end{tabular}



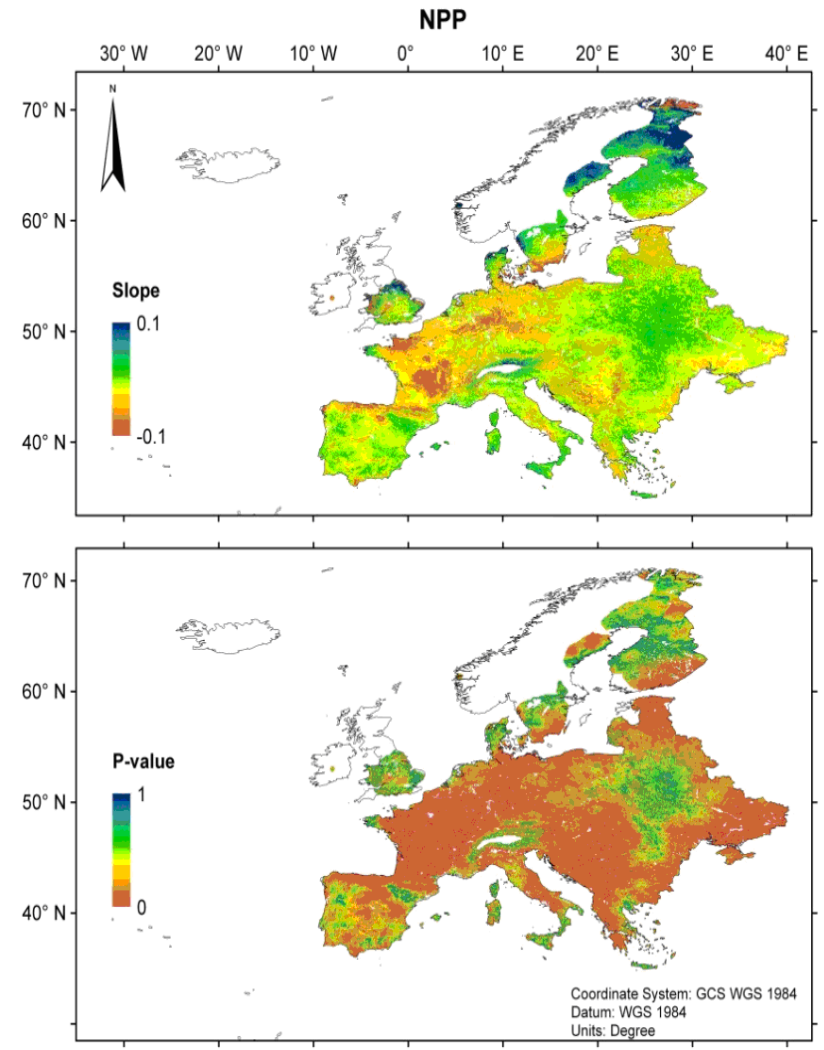

Fig. 3. Spatial distributions of the regression coefficient $\beta_{1}$ (Eq. 4) for ND25 (a) and its statistical significance (p-value) (b)

middle latitudes, while in high northern latitudes the average summer temperatures increasing stimulated the growth of the forest biomass. These results are in a good agreement with Johnsen et al. (2013) and Chertov et al. (2010). They showed the various growth responses of tree growth to a climate across a diverse and complex landscape within different latitudes. Like in the case of forests, savannas also reduced its productivity with rising of summer temperatures in the southern and middle latitudes and enhanced one in northern regions. Thus, we can conclude that the mean summer temperatures reached a threshold in Southern Europe and its subsequent growth will lead to reducing the vegetation productivity. At the same time in northern regions, the threshold has not been reached; therefore, summer temperatures increasing will stimulate the growth of vegetation.

As we can see, nowadays dynamic of vegetation productivity in Europe is not disquieting. The NPP changes were observed for less than $10 \%$ of the total vegetation area and generally had a poor positive trend. Nevertheless, despite the absence of negative evidences, analysis of relations between the vegetation productivity and temperature regime clearly shows that most European vegetation operates at its temperature optimum and further temperature increasing will lead to inhibition of plant growth (exception is Northern Europe). Summer temperatures have the strongest impact on the vegetation productivity dynamic among all concerned temperature parameters. And while in the western part of Europe this negative impact is smoothed out by maritime climate, in Eastern Europe (where the climate is more continental) we already can see the beginning of negative processes.
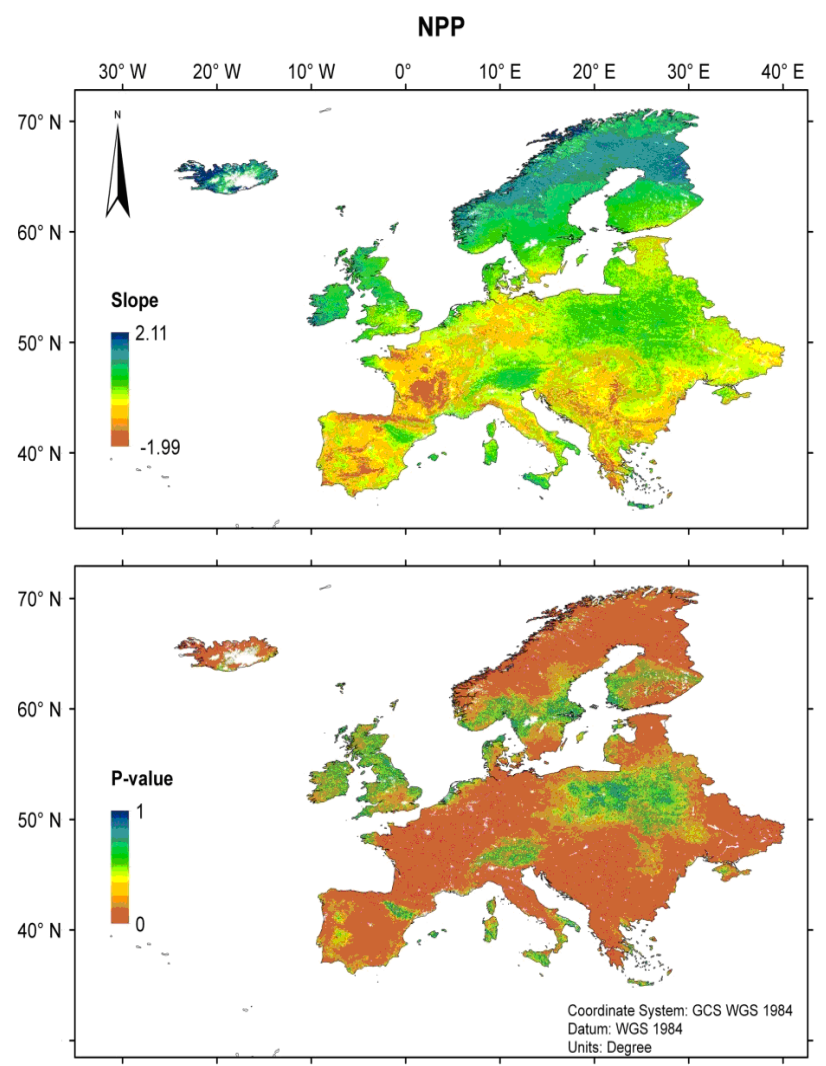

Fig. 4. Spatial distributions of the regression coefficient $\beta_{1}$ (Eq. 4) for MTsum (a) and its statistical significance (p-value) (b)

\section{Acknowledgments}

This paper is a result of work carried out for the joint Ukrainian National Academy of Sciences and International Institute for Applied Systems Analysis (Austria) project "Integrated modeling of food, energy and water security management for sustainable social, economic and environmental developments". The funding by Ukrainian National Academy of Sciences (PK No $0112 \mathrm{U} 000703$ and PK No 111U000054) is gratefully acknowledged.

\section{References}

Anderson, M. C., Norman, J. M., Meyers ,T. P., and Diak, G. R. (2000). An analytical model for estimating canopy transpiration and carbon assimilation fluxes based on canopy light-use efficiency. Agricultural and Forest Meteorology, 101, 265-289. doi:10.1016/S01681923(99)00170-7.

Bauerle, W. L., Oren, R, Way, D. A., Qian, S. S., Stoy, P. C., Thornton, P. E., Bowden, J. D., Hoffman, F. M., and Reynolds, R. F. (2012). Photoperiodic regulation of the seasonal pattern of photosynthetic capacity and the implications for carbon cycling. Proceedings of the National Academy of Sciences of the United States of America, 109, 8612-8617. doi:10.1073/pnas.1119131109.

Bonnaventure, P. P., and Lewkowicz, A. G. (2013). Impacts of mean annual air temperature change on a regional permafrost probability model for the southern Yukon and northern British Columbia, Canada. The Cryosphere, 7, 935-946, doi:10.5194/tc-7-935-2013.

Bun', R.A (Eds.). (2004). Information technologies for greenhouse gas inventories and prognosis of the carbon budget of Ukraine. Lviv, Ukrainian Academy of Printing, $376 \mathrm{pp}$. (in Ukrainian).

Chertov, O., Bhatti, J. S., and Komarov, A. (2010). Impact of Temperature 
Increase and Precipitation Alteration at Climate Change on Forest Productivity and Soil Carbon in Boreal Forest Ecosystems in Canada and Russia: Simulation Approach with the EFIMOD Model, In: Climate Change and Variability, S. Simard (eds), ISBN: 978-953307-144-2.

Clark, D. B., Olivas, P. C., Oberbauer, S. F., Clark, D. A., and Ryan, M. G. (2008). First direct landscape-scale measurement of tropical rain forest Leaf Area Index, a key driver of global primary productivity. Ecology Letters, 11, 163-172, doi:10.1111/j.14610248.2007.01134.x.

Corlett, R. T. (2011). Impacts of warming on tropical lowland rainforests. Trends in Ecology \& Evolution, 26, 606-613, doi:10.1016/ j.tree.2011.06.015.

de Jong, R., Schaepman, M. E., Furrer, R., de Bruin, S., and Verburg, P. H. (2013). Spatial relationship between climatologies and changes in global vegetation activity. Global Change Biology, 19, 1953-1964, doi:10.1111/gcb.12193.

Dee, D. P., Uppala, S. M., Simmons, A. J., Berrisford, P., Poli, P., Kobayashi, S., Andrae, U., et al. (2011). The ERA-Interim reanalysis: configuration and performance of the data assimilation system. Quarterly Journal of the Royal Meteorological Society, 137(656), 553-597. doi:10.1002/qj.828.

Elmendorf, S. C., Henry, G. H. R., Hollister, R. D., Björk, R. G., Bjorkman, A. D., Callaghan, T. V., Collier, L. S. et al. (2011). Global assessment of experimental climate warming on tundra vegetation: heterogeneity over space and time. Ecology Letters, 15, 164-175. doi:10.1111/j.1461-0248.2011.01716.x.

Frank D., Reichstein, M., Bahn, M., Thonicke, K., Frank, D., Mahecha, M. D., Smith, P. et al. (2015). Effects of climate extremes on the terrestrial carbon cycle: concepts, processes and potential future impacts. Global Change Biology, 21(8), 2861-2880. doi:10.1111/gcb.12916.

Gornall, J., Betts, R., Burke, E., Clark, R., Camp, J., Willett, K., and Wiltshire, A. (2010). Implications of climate change for agricultural productivity in the early twenty-first century. Philosophical Transactions of the Royal Society B, 365, 2973-2989. doi:10.1098/ rstb.2010.0158.

Groisman, P, and Lyalko, V., eds. (2012). Earth Systems Change over Eastern Europe. Kyiv, Akademperiodyka, 488 p., ISBN 978-966360-195-3.

Hartmann, D. L., Klein Tank, A.M.G., and Rusticucci, M. (2013). Observations: Atmosphere and Surface, In: Climate Change 2013: The Physical Science Basis. Contribution of Working Group I to the Fifth Assessment Report of the Intergovernmental Panel on Climate Change ( Stocker, T.F., D. Qin, G.-K. Plattner, M. Tignor, S.K. Allen, J. Boschung, A. Nauels, Y. Xia, V. Bex and P.M. Midgley (eds.), Cambridge University Press, Cambridge, United Kingdom and New York, NY, USA, 159-254.

Heimann, M., and Reichstein, M. (2008). Terrestrial ecosystem carbon dynamics and climate feedbacks. Nature, 451, 289-292. doi:10.1038/ nature 06591 .

Heinsch, F. A., Reeves, M., Votava, P., Kang S., Milesi, C., Zhao, M., Glassy, J. et al. (2003). User's Guide GPP and NPP (MOD17A2/A3) Products NASA MODIS Land Algorithm. Version 2.0, December; 57 pp.

Houghton, R. (2005). Aboveground forest biomass and the global carbon balance. Global Change Biology, 11, 945-958, doi:10.1111/j.13652486.2005.00955.x.

IPCC. (2001). The Scientific Basis, In: Climate Change 2001: Contribution of Working Group I to the Third Assessment Report of the Intergovernmental Panel on Climate Change. Houghton, J. T., Ding, Y., Griggs, D. J., Noguer, M., van der Linden, P. J., Dai, X., Maskell, K., Johnson, C. A. (eds), Cambridge University Press, Cambridge, United Kingdom and New York, NY, USA, 881 pp.

IPCC. (2007). Impacts, Adaptation and Vulnerability, In: Climate Change
2007: Contribution of Working Group II to the Fourth Assessment Report of the Intergovernmental Panel on Climate Change. Parry, M., Canziani, O. F., Palutikof, J. P., van der Linden, P. J., Hanson, C. E. (eds), Cambridge University Press, Cambridge, UK; $976 \mathrm{pp}$.

IPCC. (2013). The Physical Science Basis, In: Climate Change 2013: Contribution of Working Group I to the Fifth Assessment Report of the Intergovernmental Panel on Climate Change. Stocker, T. F., Qin, D., Plattner, G-K., Tignor, M., Allen, S. K., Boschung, J., Nauels, A., Xia, Y., Bex, V., Midgley, P. M. (eds). Cambridge University Press, Cambridge, United Kingdom and New York, NY, USA; 1535 pp.

Johnsen, K. H., Keyser, T. L., Butnor, J. R., Gonzalez-Benecke, C. A., Kaczmarek, D. J., Maier, C. A., McCarthy, H. R., Sun, G. (2013). Productivity and Carbon Sequestration of Forests in the Southern United States, In: Climate Change Adaptation and Mitigation Management Options: A Guide for Natural Resource Managers in Southern Forest Ecosystems, CRC Press, 193-247.

Lin, D, Xia, J, Wan, S. (2010). Climate warming and biomass accumulation of terrestrial plants: A meta-analysis. New Phytologist, 188, 187-198. doi:10.1111/j.1469-8137.2010.03347.x.

Lu, M., Zhou, X., Yang, Q., Li, H., Luo, Y., Fang, C., Chen, J., Yang, X., and Li, B. (2013). Responses of ecosystem carbon cycle to experimental warming: a meta-analysis. Ecology, 94, 726-738. doi:10.1890/12-0279.1.

McCallum, I., Wagner, W., Schmullius, C., Shvidenko, A., Obersteiner, M., Fritz, S., and Nilsson, S. (2009). Satellite-based terrestrial production efficiency modeling. Carbon Balance and Management, 4-8. doi:10.1186/1750-0680-4-8.

Mohamed, M. A., Babiker, I. S., Chen, Z. M., Ikeda, K., Ohta, K., and Kato, K. (2004). The role of climate variability in the inter-annual variation of terrestrial net primary production (NPP). Science of the Total Environment, 332, 123-137. doi:10.1016/ j.scitotenv.2004.03.009.

Movchan, D. and Kostyuchenko, Yu. V. (2015). Regional dynamics of terrestrial vegetation productivity and climate feedbacks for territory of Ukraine. International Journal of Geographical Information Science, 29(8), 1490-1505. doi: 10.1080/13658816.2015.1051985.

Mu, Q., Zhao, M., and Running, S.W. (2011). Evolution of hydrological and carbon cycles under a changing climate. Hydrological Processes, 25(26), 4093-4102. doi:10.1002/hyp.8367.

Piao, S., Fang, J., Zhou, L., Zhu, B., Tan, K., and Tao, S. (2005). Changes in vegetation net primary productivity from 1982 to 1999 in China. Global Biogeochemical Cycles, 19(2), GB2027. doi:10.1029/ $2004 \mathrm{~GB} 002274$.

Piao, S., Sitch, S., Ciais, P., Friedlingstein, P., Peylin, P., Wang, X., Ahlström, A. et al. (2013). Evaluation of terrestrial carbon cycle models for their response to climate variability and to $\mathrm{CO}_{2}$ trends. Global Change Biology, 19(7), 2117-2132. doi:10.1111/gcb.12187.

Piao, S., Friedlingstein, P., Ciais, P., Viovy, N., and Demarty, J. (2007). Growing season extension and its impact on terrestrial carbon cycle in the Northern Hemisphere over the past 2 decades. Global Biogeochemical Cycles, 21, 49-53. doi:10.1029/2006gb002888.

Porter, J. R., and Semenov, M. A. (2005). Crop responses to climatic variation. Philosophical Transactions of the Royal Society B, 360, 2021-2035. doi:10.1098/rstb.2005.1752.

Running, S. W., Thornton, P. E., Nemani, R., and Glassy, J. M. (2000). Global terrestrial gross and net primary productivity from the Earth observing system, In: Methods in Ecosystem Science, (esd Sala OE et al), Springer, New York, 44-57

Strahler, A. H., Friedl, M., Zhang, X., Hodges, J., Schaaf, C., Cooper, A., and Baccini, A. (2002). The MODIS Land Cover and Land Cover Dynamics Products. Presented at Remote Sensing of the Earth's Environment from TERRA. L'Aquila, Italy.

Wu, Z., Dijkstra, P., Koch, G. W., Peñuelas, J., and Hungate, B. A. (2011). 
Responses of terrestrial ecosystems to temperature and precipitation change: A meta-analysis of experimental manipulation. Global Change Biology, 17, 927-942. doi:10.1111/j.1365-2486.2010.02302.x.

Zhang, X., Tarpley, D., and Sullivan, J. T. (2007). Diverse responses of vegetation phenology to a warming climate. Geophysical research letters, 34, L19405. doi:10.1029/2007GL031447.

Zhao, M., Running S. W., and Nemani R. R. (2006). Sensitivity of Moderate Resolution Imaging Spectroradiometer (MODIS) terrestrial primary production to the accuracy of meteorological reanalyses. Journal of Geophysical Research, 111, G01002. doi:10.1029/ 2004JG000004.

Zhou, L., Tucker, C. J., Kaufmann, R. K., Slayback, D., Shabanov, N. V., and Myneni, R. B. (2001). Variations in northern vegetation activity inferred from satellite data of vegetation index during 1981 to 1999. Journal of Geophysical Research: Atmospheres 106(D17), 2006920083. doi:10.1029/2000JD000115.

\section{ПРОСТОРОВО-ЧАСОВИЙ АНАЛІЗ ТРЕНДУ ПРОДУКТИВНОСТІ РОСЛИННОГО ПОКРИВУ В ЄВРОПІ 3 ВИКОРИСТАННЯМ СУПУТНИКОВИХ ДАНИХ MODIS}

Д. М. Мовчан

ДУ “Науковий центр аерокосмічних досліджень Землі ІГН НАН України”. E-mail: dmovchan@hotmail.com, тел.: +380956077578, вул. О. Гончара 55-Б, Київ, 01054, Україна. ORCID: 0000- 0003-0176-7740

Проведені попередні дослідження показали, що зміна температурного режиму впливає на біогеохімічні процеси в екосистемах. Для прикладу, лабораторні експерименти з підвищенням температури приводили до інтенсифікації фотосинтезу і збільшення продуктивності рослинності i накопичення біомаси (Elmendorf et al., 2012; Lin et al., 2010; Lu et al., 2013; Wu et al., 2011). Однак подібного роду зв'язок не є таким очевидним в природних умовах (Mohamed et al., 2004). У цьому дослідженні представлені результати попіксельного аналізу регіональних тенденцій продуктивності рослинного покриву, який був проведений для європейської території. Для аналізу тенденцій чистої первинної продуктивності (ЧПП) були використані дані часових рядів спектрометра середньої роздільної здатності (MODIS). Були проведені оцінки змін запасів вуглецю в грунті, спричинені динамікою продуктивності рослинності. Була виявлена негативна тенденція зменшення продуктивності рослинності в Східній Європі. Було встановлено, що головним температурним фактором негативного впливу на продуктивність рослинності в Західній, Східній і Південній Європі було підвищення літніх температур. Отримані дані свідчать про те, що в Південній Європі середні літні температури досягли свого порогу, і їх подальше зростання з великою ймовірністю буде сприяти зниженню продуктивності рослинності. У той же час в північних регіонах поріг ще не досягнутий, отже, підвищення літніх температур буде стимулювати зростання рослинності. Аналізуючи зміни для різних типів рослинності, можна відзначити, що запаси вуглецю на сільськогосподарських угіддях скоротилися на 2.67 млн т, в той час як ліси і луки показали позитивну динаміку (запаси вуглецю збільшилися на 1.64 і 3.7 млн т відповідно). Загальні результати по всьому європейському регіону вказують на позитивну тенденцію (2.67 млн т) стоку вуглецю в наземну рослинність. Ключові слова: продуктивність рослинного покриву, зміна клімату, дистанційне зондування Землі, запас вуглецю, MODIS

ПРОСТРАНСТВЕННО-ВРЕМЕННОЙ АНАЛИЗ ТРЕНДА ПРОИЗВОДИТЕЛЬНОСТИ РАСТИТЕЛЬНОГО ПОКРОВА В ЕВРОПЕ С ИСПОЛЬЗОВАНИЕМ СПУТНИКОВЫХ ДАННЫХ МODIS

\section{Д. М. Мовчан}

ГУ “Научный центр аэрокосмических исследований Земли ИГН НАН Украины”. E-mail: dmovchan@hotmail.com, тел.: +380956077578, ул. О. Гончара 55-Б, Киев, 01054, Украина. ORCID: 0000- 0003-0176-7740

Проведенные предыдущие исследования показали, что изменение температурного режима оказывает существенное влияние на биогеохимические процессы в экосистемах. Для примера, лабораторные эксперименты с повышением температуры приводили к интенсификации фотосинтеза и увеличению продуктивности растительности и накоплению биомассы (Elmendorf et al., 2012; Lin et al., 2010; Lu et al., 2013; Wu et al., 2011). Однако подобного рода связь не так очевидна в естественных условиях (Моһamed еt al., 2004). В этом исследовании представлены результаты попиксельного анализа региональных тенденций продуктивности растительного покрова, который был проведен для европейской территории. Для анализа тенденций чистой первичной производительности (ЧПП) были использованные данные временных рядов спектрометра среднего разрешения (MODIS). Были проведены оценки изменений запасов углерода в почве, вызванные динамикой продуктивности растительности. Была обнаружена негативная тенденция уменьшения продуктивности растительности в Восточной Европе. Было установлено, что главным температурным фактором отрицательного влияния на продуктивность растительности в Западной, Восточной и Южной Европе было повышение летних температур. Полученные данные свидетельствуют о том, что в Южной Европе средние летние температуры достигли порога, и их последующий рост с большой вероятностью будет способствовать снижению продуктивности растительности. В то же время в северных регионах порог еще не достигнут, следовательно, повышение летних температур будет стимулировать рост растительности. Анализируя изменения для различных типов растительности, можно отметить, что запасы углерода на сельскохозяйственных угодьях сократились на 2.67 млн т, в то время как леса и луга показывают положительную динамику (запасы углерода увеличились на 1.64 и 3.7 млн т соответственно). Общие результаты по всему европейскому региону указывают на положительную тенденцию (2.67 млн т) стока углерода в наземную растительность.

Ключевые слова: производительность растительного покрова, изменение климата, дистанционное зондирование Земли, запас углерода, MODIS 